\title{
COLUMN
}

\section{De Urgenda-uitspraak: wetgever en regering onder verscherpt rechterlijk toezicht}

\author{
Rolf Ortlep
}

Het is bijna als uilen naar Athene dragen om iets te zeggen over de recente Urgenda-uitspraak. ${ }^{1}$ In de literatuur zijn immers over die uitspraak al vele pennenvruchten verschenen. ${ }^{2}$ Is er dan zo veel bijzonders aan de hand? Dat kan niet met recht worden ontkend.

Deze civielrechtelijke zaak tegen de Staat is aangespannen door de Stichting Urgenda, ${ }^{3}$ omdat de overheid volgens haar de urgentie van het klimaatprobleem weliswaar erkent, maar te weinig maatregelen neemt om gevaarlijke klimaatverandering te voorkomen. In de Urgenda-uitspraak wordt de Staat, op basis van de in artikel 6:162 van het Burgerlijk Wetboek neergelegde maatschappelijke zorgvuldigheidsnorm, op straffe van een dwangsom bevolen om de jaarlijkse emissies van broeikasgassen in het jaar 2020 met ten minste 25 procent te beperken vergeleken met het niveau van het jaar 1990. De voor die zaak relevante internationale bepalingen zijn in rechte niet inroepbaar bij de nationale rechter, in de zin dat zij ongeschikt zijn om rechtstreeks als objectief recht in de nationale rechtsorde te functioneren en zij zijn daarom niet eenieder verbindend in de zin van de artikelen 93 en 94 van de Grondwet (Gw). Evenwel past de rechtbank de zogeheten reflexwerking toe. Met het laatste wordt bedoeld dat de rechter bij de toepassing van nationaalrechtelijke open normen, zoals de maatschappelijke zorgvuldigheidsnorm, rekening houdt met internationale bepalingen die niet eenieder verbindend in de zin van de artikelen 93 en $94 \mathrm{Gw}$ zijn.

Vooralsnog is (de grondredenering van) de Urgenda-uitspraak in de rechtspraak niet herhaald en lijkt het ter zake alleen te gaan om internationale bepalingen waarin een concrete (in percentages uitgedrukte) norm is opgenomen. Te wijzen

1 Rb. Den Haag 24 juni 2015, ECLI:NL:RBDHA:2015:7145.

2 Vergelijk slechts R.J.B. Schutgens, Urgenda en de trias, NJB 2015, p. 2270-2277; L. Bergkamp, Het Haagse klimaatvonnis, NJB 2015, p. 2278-2288; S.M.N. Fikkers, Urgenda, de zorgplicht en toekomstige generaties, NJB 2015, p. 2289-2293; M.A. Loth \& R.A.J. van Gestel, Urgenda: roekeloze rechtspraak of rechtsvinding 3.0, NJB 2015, p. 2598-2605; R.A.J. van Gestel, Urgenda: een typisch gevalletje rechter, wetgever of politiek?, Regelmaat 2015, p. 384-396; G. Boogaard, Urgenda en de rol van de rechter. Over de ondraaglijke leegheid van de trias politica, AA 2016, p. 26-33; A.G. Castermans, Het klimaatgevaar en het gouden kelderluik, AA 2016, p. 34-40; R. van der Hullu \& L. Van Heijningen, Het wetgevingsbevel vanuit Unierechtelijk perspectief: het debat heropend, SEW 2016, p. 11-18.

3 De Stichting Urgenda is de organisatie voor duurzaamheid en innovatie die Nederland, samen met bedrijven, overheden, maatschappelijke organisaties en particulieren, sneller duurzaam wil maken. 
is op de uitspraak van de Rechtbank Den Haag van 9 november 2015. ${ }^{4}$ Hierin gaat het om artikel 5 lid 3 van het Kaderverdrag van de World Health Organization (hierna: WHO-Kaderverdrag), waarin het volgende is bepaald:

'Bij de vaststelling en uitvoering van hun volksgezondheidsbeleid met betrekking tot tabaksontmoediging, nemen Partijen, in overeenstemming met het nationaal recht, maatregelen om dit beleid te beschermen tegen commerciële en andere gevestigde belangen van de tabaksindustrie.'

De Stichting Rookpreventie Jeugd heeft in de procedure als inzet om de Staat op grond van de in artikel 5 lid 3 WHO-Kaderverdrag vervatte norm te houden om maatregelen te treffen die de bemoeienis van de tabaksindustrie verder terugbrengt. Nadat de rechtbank heeft vastgesteld dat artikel 5 lid 3 WHO-Kaderverdrag niet eenieder verbindend in de zin van de artikelen 93 en $94 \mathrm{Gw}$ is, buigt zij zich over de reflexwerking. De rechtbank oordeelt dat er geen aanleiding is voor de door de stichting onder verwijzing naar de Urgenda-uitspraak bepleite toepassing van de reflexwerking. Die zaak onderscheidt zich naar het oordeel van de rechtbank van de Urgenda-zaak omdat in de laatstgenoemde zaak

'een concrete (in percentages uitgedrukte) norm ter vermindering van de uitstoot van broeikasgassen die in de klimaatwetenschap en het internationale klimaatbeleid noodzakelijk wordt geacht voor geïndustrialiseerde landen als Nederland teneinde een gevaarlijke klimaatverandering tegen te gaan, leidend is geweest voor het oordeel van de rechtbank dat de maatschappelijke zorgvuldigheidsnorm was geschonden. Een dergelijke duidelijke norm ontbreekt nu juist in artikel 5, derde lid, van het WHO-Kaderverdrag.'

Over de Urgenda-uitspraak heeft het kabinet, bij monde van staatssecretaris mevrouw Mansveld, het volgende opgemerkt:

'Nationaal zijn de Kamer en het kabinet aan zet om het klimaatbeleid te formuleren. Dat is logisch, want de discussie moet gevoerd worden waar die gevoerd moet worden. Dat is hier in de politieke arena. Door het vonnis in de zaak die door Urgenda is aangespannen, verschuift die discussie naar de rechtszaal. Het is de vraag of de rechter op de stoel van parlement en regering is gaan zitten. Mede daarom heeft het kabinet besloten om de uitspraak te laten toetsen door een hogere rechter op een viertal punten. Dat zijn: de zorgplicht, de beleidsvrijheid van de Staat, het causale verband tussen uitstoot in Nederland en het gevaar dat ontstaat door klimaatverandering en de vaststelling en de interpretatie van de feiten. ${ }^{5}$

4 Rb. Den Haag 9 november 2015, ECLI:NL:RBDHA:2015:12746. Deze civielrechtelijke zaak tegen de Staat is aangespannen door de Stichting Rookpreventie Jeugd. De rechterlijke uitspraak ligt in het verlengde van het door de Hoge Raad gewezen Rookverbod-arrest van 10 oktober 2014, ECLI:NL:HR:2014:2928.

5 Handelingen Tweede Kamer 2015/16, nr. 6, item 4, 6417-6418. Vergelijk Kamerstukken II 2014/15, 32813, nr. 103. 
Uit dit citaat volgt dat het kabinet zich naar aanleiding van de Urgenda-uitspraak onder meer zorgen maakt over de mogelijke precedentwerking van die uitspraak. Het gaat er dan met name om dat het bevel tot reduceren treedt in de beleidsvrijheid van de Staat en dat een dergelijk bevel is ingegeven door de hierboven benoemde reflexwerking van internationale bepalingen die niet eenieder verbindend in de zin van de artikelen 93 en $94 \mathrm{Gw}$ zijn. Ook de heer Voermans heeft in de Volkskrant van 28 augustus 2015 hierop gewezen. Hij acht het onwenselijk dat een (uit het internationale recht afkomstige) zorgplicht voor de Staat omslaat in een in rechte afdwingbare aanspraak voor een burger. Ter zake noemt hij het voorbeeld van de afspraken die de Nederlandse Staat heeft gemaakt in verband met het Europese Stabiliteits- en Groeipact 1997. Deze afspraken houden in dat het Nederlandse begrotingstekort niet groter dan 3 procent en de staatsschuld niet groter dan 60 procent van het bruto binnenlands product mag zijn. In de jaren 2013 en 2014 was het begrotingstekort groter dan 3 procent en al meer dan vijf jaar lang is de Nederlandse staatsschuld groter dan 60 procent van het bruto binnenlands product.

'Moeten burgers', aldus de heer Voermans, 'of een vereniging de mogelijkheid krijgen minister Dijsselbloem van Financiën op straffe van een dwangsom te dwingen die doelstellingen te behalen, omdat de belanghebbenden dat belangrijker vinden dan alle andere onderdelen van beleidsvoering? Natuurlijk niet.'

Hetgeen hierboven is besproken roept de vraag op of door de Urgenda-uitspraak de wetgever en de regering onder verscherpt rechterlijke toezicht staan. Dit lijkt mij buiten kijf te staan. Een belangrijkere vraag is of dit ongewenst is. Over het antwoord op deze vraag zou naar mijn inschatting nimmer eensgezindheid bestaan, daar het raakt aan de relatief oude discussie of de rechter mag treden in aangelegenheden die traditioneel tot de bevoegdheden van de wetgever en de regering behoren. Een veel gelezen argument in die discussie is dat de rechterlijke bevoegdheid zich niet mag uitstrekken over politieke keuzen, aangezien een Nederlandse rechter niet is gekozen door het volk ${ }^{6}$ en deze daarom geen democratische en politieke legitimiteit heeft. ${ }^{7}$ Het is voor mij opmerkelijk dat dat argument in die discussie nog steeds wordt aangedragen, althans zonder de hierna volgende nuanceringen. Het is wellicht bij de lezer bekend dat de heer Martens, in zijn afscheidsrede als president van de Hoge Raad, over de bewering dat de rechter niet democratisch gelegitimeerd is, heeft opgemerkt dat zij zinloos is.

'Zeker', aldus in zijn woorden, 'de legitimatie van de rechter ligt niet daarin dat hij is verkozen. Maar de grondslag van ons staatsbestel is niet enkel de representatieve democratie, doch óok en vooral the rule of law: Nederland is

6 Vergelijk P.P.T. Bovend'Eert, Meer of minder parlementaire betrokkenheid bij rechtersbenoemingen?, in: R. Baas e.a. (red.), Rechtspleging en rechtsbescherming (De Groot-van Leeuwenbundel), Deventer: Kluwer 2015, p. 141-150.

7 Zie voor het noemen en bespreken van dat argument de literatuur genoemd in voetnoot 2. 
een rechtsstaat. De rechtsstaat is onbestaanbaar zonder rechtsprekende macht die is geroepen tot "overeenkomstig de wet" rechtspreken en daarmee [...] tevens tot rechtsvorming. De legitimatie van de rechtsprekende macht is dus anders van aard, maar daarom niet minder dan die van de beide andere machten van de trias politica.' ${ }^{8}$

In een ander geschrift heb ik - onder verwijzing van anderen - hieraan toegevoegd dat ook vanuit een andere invalshoek het 'gebrek' aan democratische legitimatie van de rechter genuanceerd dient te worden, in de zin dat een dergelijke legitimatie niet alleen gelijkgesteld moet worden aan representatieve democratie. ${ }^{9}$ Door onder meer de groeiende verwevenheid van de nationale rechtsorde met de internationale rechtsorde en het in relatieve zin gebrek aan democratisch gelegitimeerde internationale wetgeving en besluitvorming is de taak van rechterlijke rechtsvorming autonomer geworden. Ook in die zin heeft de heer Martens gelijk dat de bewering dat de rechter niet democratisch gelegitimeerd is, zinloos is. Anders dan bij politieke organen - lees: de wetgever en de regering - is het optreden van de (Nederlandse) rechter niet gelegitimeerd door electoraat of politieke verantwoordelijkheid, maar dient de legitimatie van dat optreden gevonden te worden in de motivering van zijn uitspraken. Dat de wetgever en de regering met een dergelijke legitimatie onder verscherpt rechterlijke toezicht staan, lijkt mij niet iets dat met recht als ongewenst kan worden bestempeld.

8 S.K. Martens, De grenzen van de rechtsvormende taak van de rechter, NJB 2000, p. 747-758, i.h.b. p. 751.

9 R. Ortlep, Optimaliseren rechtseenheid tussen de hoogste bestuursrechters, in: E.M.H. Hirsch Ballin e.a., Rechtsontwikkeling door de bestuursrechter. VAR-reeks 154, Den Haag: Boom Juridische uitgevers 2015, p. 117-118. 